\title{
Geneses and Progress of the World Campaign and Council For The Biosphere*
}

\author{
by \\ Nicholas Polunin, D.Phil., D.Sc.(Oxon), CBE \\ President of the World Council For The Biosphere and of the Foundation \\ for Environmental Conservation; \\ Secretary-General and Editor of the International Conferences on Environmental Future; \\ Founder and Editor of Environmental Conservation; \\ Convener \& General Editor of Environmental Monographs \& Symposia, \\ 7 Chemin Taverney, 1218 Grand-Saconnex, Geneva, Switzerland.
}

\section{Our Definition}

Let us first define the meanings which we attach to the words in our title-in our mother tongue of English but for an international audience. 'Genesis' was the choice of Secretary-General Craig Davis and commonly means 'origin' or 'mode of formation'-or, in our immediate context, both of them together or to some extent in sequence (as being partly developmental). Here we use the plural, Geneses, as there are two interdependent items involved, though Progress means such advance as can be seen in the movement which they foster. World, used thus adjectivally, means spanning the world and being as ubiquitously global as such an initiative can possibly be, and Campaign characterizes an organized course of action with a definite objective, while Council means a deliberative cum advisory body that counsels-in this case, as much as possible of the enlightened world. Biosphere (with capitalization also of the initial letter of 'The' [sic] when immediately preceding it) we define as: The integrated living and life-supporting system comprising the peripheral envelope of Planet Earth together with its surrounding atmosphere so far down, and up, as any form of life exists naturally.

It is quite ardently to be hoped that this last definition ${ }^{\dagger}$ will be universally adopted and effectively exclude use of the term Biosphere in any other sense-including, particularly, the very different one of the 'web-of-life' or of living matter alone in which it is still apt to be employed even in some learned journals. This sphere- or envelopeof-life definition was unanimously voted for adoption at the Symposium Banquet of the Miami International Symposium on The Biosphere, as recounted on page 189 of our last preceding issue of Environmental Conservation (Summer 1984). However, as the Miami Symposium had no powers in this matter vis-à-vis the rest of the world, but itself gave it the all-important backing of consistent (I think, and certainly persistent) use, it would I feel be useful to ask whether we in this very different

\footnotetext{
*Based primarily on the opening address to Session I of the International Workshop on Development and Biosphere Stability, held at the Vigyan Bhawan, New Delhi, India, on 2 June 1984-see the report on pp. 371-3 of this issue.

† as explained in the Editorial Note on page 198 of our preceding issue.
}

gathering are in agreement with this employment of the term Biosphere only for the 'envelope of life', and, if we are, record the fact. ${ }^{\dagger}$

\section{Biosphere: Concept and Actuality}

As we have defined it, The Biosphere is the totality of living and life-support systems occupying the peripheral envelope of Planet Earth together with its surrounding atmosphere so far down, and up, as living things exist naturally. It thus constitutes a vast hollow near-sphere ranging from the deepest rock strata and bottoms of troughs in oceans, upwards to the highest levels of the atmosphere, in which any form of life-including chemosynthetic bacterial or other cells or dormant spores-is present without human intervention, for we exclude artificial projections into space and other Manengendered feats.

The Biosphere is thus at once an imaginative concept and something that is scientifically very real, that lies all around us-unless we are away from it quite artificially in outer space. In reality it is our own and Nature's lifesupport system, of which we and other biota form an integral part, on which we are all utterly dependent for our wherewithal of life, but which we are threatening more and more severely with our ever-increasing numbers and profligate use of earthly living-space and other essential but limited raw-materials. Surely it behoves us to understand the concept and safeguard the integrity of The Biosphere!

\section{Importance of Knowledge and Understanding}

As was indicated in the 'Open Letter: To All Who Should be Concerned' ${ }^{\dagger \dagger}$ our Biosphere is a highly complex 'integrated system of sunshine, and water, minerals, and living organisms, comprising the peripheral sphere of the Earth', that needs understanding-particularly regarding its 'limits in terms of carrying capacity for human life' (Pauling et al., 1982; cf. Polunin 1972, 1982; Anon., 1982). That requires ever-more knowledge, research, and testing of findings and ideas. At least from the strato-

++ Preceding the publication of the Declaration of the World Campaign for The Biosphere (in Environmental Conservation, Vol. 9, No. 2, Summer 1982), and signed by leading individuals in all the six normally-inhabited continents of the world (Pauling et al., 1982). 
spheric ozone shield downwards to the lower layers of subterranean ground-water, The Biosphere needs understanding in as many as possible of its myriad components, actions, reactions, and interactions, that together make up our living system.

The biggest potential for good or evil, at least if we take the benefit or otherwise of The Biosphere as our criterion, probably lies in the human brain, which can perpetrate effective safeguarding or-especially with nuclear energy-widespread destruction. We have to secure the former and prevent the latter- a duality of imperatives that become more and more trying and even problematical as human population-pressures build up.

Let me now spell out a 'round dozen' of key facts about The Biosphere which our readers will mostly know but which should surely be part also of the wider world's common knowledge:

1) The Biosphere is an integrated super-system-a 'whole' of which the components are intricately interdependent both locally and also very widely.

2) In its operation evolving over several thousand million years, The Biosphere has given rise to countless millions of species and other taxa of biota of which many continue to live within it.

3) Mankind is one of these species, with, however, the unique endowment of conscious intelligence that makes him practically all-powerful.

4) As consumers we humans draw our essential resources of air, water, food, warmth, and spiritual energy, from The Biosphere, and are therefore completely dependent on its great cycles, vast production, and ecological integrity, for our well-being and very existence.

5) The carrying capacity of The Biosphere for satisfying human life, which may be raised by technology but all too easily and widely lowered by its aftermath, is nevertheless limited under specific conditions and times.

6) What these limits are now, or may turn out to be in the future, is neither known nor perhaps even knowable except in retrospect.

7) Because of the present uncertainties concerning human populations and their effects on The Biosphere, it would be prudent to guard against foreseeable constraints on it as far as possible in advance and in every conceivable context and way.

8) Reciprocally, because of the virtual unpredictability of the reactions and responses of The Biosphere to human actions, it would be prudent-always bearing in mind our absolute dependence on The Biosphere-to guard against imposing restraints on it of any conceivable kind.

9) The most dangerous threats to life, including those to Mankind, are often the quietly insidious ones-such as those to the stratospheric ozone shield-against which we must be constantly on the alert and should be ready to take action when necessary on a global scale.

10) Yet the most dangerous and immediate threat to life as we know it is that of thermonuclear holocaust, against precluding which we must do everything we possibly can. For there are not only the great powers threatening - who seem unlikely to start anything intentionally as they know the appalling consequences, and that nobody could really win-but also smaller ones, as well as grave possibilities of mechanical failure or malfunctioning, human or computer error, or even sheer accident. There is also the problem of mental imbalance in our stressfully crowded world, and of somebody in a tither 'pressing the wrong button'.

11) A particularly grave aspect of the human etc. error point is the psychological one-that under the extreme pressure and stresses of hyper-responsibility and in time doubtless incapacitating fatigue, leaders or others could make wrong decisions, and, "perhaps based on misinterpretation or misinformation, start a nuclear holocaust.

12) The one thing that Mankind seems incapable of doing, though now amply possessed of the knowledge and means, is peaceful limitation of its own population, which continues increasingly, if insidiously, to impose the next-greatest threat after nuclear ones; yet even Mankind cannot go on growing-demographically and, still less, demophorically-on a finite globe: the farther he goes, the greater will be the fall, which surely poses our greatest long-term dilemma.

Those are my 'round dozen' choices for our present and another recent occasion, but one could almost as easily have added another dozen of such concerns as:

1) Government indifference to the welfare of The Biosphere.

2) Economic disparity between so-called rich and poor nations and the debt-engendered instability of the former.

3) Toxic pollutions including long-range airborne acidification.

4) Deforestation and other devegetation, even to an extent that could affect the atmospheric supply and content of oxygen.

5) Ever-more and -wider soil depletion and erosion.

6) Inexorably expanding desertification.

7) Increasing terrestrial salinization and alkalization especially with more and more irrigation.

8) Breakdown of communications on which humanity has become increasingly dependent.

9) Carbon-dioxide changes engendering climatic changes.

10) Threats to the stratospheric ozone shield.

11) Constriction and depletion of food-producing land.

12) Loss of genetic resources, especially with monocultures replacing natural forests.

Those are the kinds of facts or foreseeabilities which we ought to 'shout from the housetops', so that, above all, the politicians and decision-makers are made fully aware and really alert to their responsibilities in a context of hard scientific reality.

\section{Education the Key}

It is a trite thing to say, but surely our world needs saving from itself-from destruction perpetrated by 
Mankind, its uniquely intelligent component! This will require action on a global scale, consciously in the context of The Biosphere as a whole; thus even the tiniest bits may be part of something vital to this whole, such that it cannot continue healthy-or perhaps even at allwithout them. For as we said in our No. 1 point about The Biosphere, it constitutes one integrated whole of which the components are widely interdependent.

To grasp these matters, and especially to do basic research or applicational testing towards global survival in any of its manifold and continuingly unfolding aspects, requires appropriate education-hence the propitious establishment of the International Society For Environmental Education (ISEE), concerning which you will have read in the Guest Editorial by its foundation's moving spirit, Professor Craig B. Davis (cf. 1983), who, most appropriately and properly, has become SecretaryGeneral of the joint bodies WCB-ISEE.

\section{The World Campaign for The Biosphere}

It was realization of the vital need of this education that led to attempts-largely abortive but surely not wasted - to establish an 'International Year' and subsequently 'World Decade' of The Biosphere, the former beginning with and indeed largely at the instance of our good friend and fellow Councillor, Dr John R. Vallentyne, of Canada, former long-time President of the International Society of Limnology, perhaps better known as SIL (Socitas Internationalis Limnologiae). Later on we instituted the World Campaign for The Biosphere, the Declaration of which was circulated and read out at various centres-including New Delhi by Professor Ramdeo Misra and both Ottawa and Calgary, Canada, by myself-on World Environment Day, 5 June 1982. It was published in the Summer 1982 issue of Environmental Conservation (Anon., 1982) and was subsequently reprinted plurally elsewhere.

The stated aims and objectives of the World Campaign for The Biosphere are:

(i) to develop, and foster on a continuing basis, educational programmes and allied activities designed to make the concept [and reality] of Our Biosphere intimately known and personally meaningful to people of all ages and cultures throughout the world;

(ii) to further the development of scientific understanding of the design and operation of The Biosphere;

(iii) therefrom to prepare for, launch, and guide, practical actions towards safeguarding our one and only Biosphere; and

(iv) to encourage the development of political and other institutions to reduce the physical and spiritual harm which we inflict unnecessarily on ourselves and Nature by failing to accommodate The Biosphere's ways and needs' (Anon., 1982).

\section{Furthering the World Campaign}

The following is a boil-down of a dozen of the means that we have already proposed in various publications, and in some cases have already become activated, for furthering and maintaining the World Campaign for The Biosphere:
1) Publishing and broadcasting information and support by all appropriate means:-This should include editorials, survey articles, and research papers in highlevel journals, and also invoke the 'popular' press through chronic involvement of leading internationallyoriented newspapers.

2) Using other vehicles of desirable publicity, including posters and stickers:-Persistently involved should be such further 'media' as television-in which several recent initiatives based particularly in London, England, are to be welcomed-documentary and even fictional films and writings, radio broadcasting, the pulpit, and even the 'legitimate' stage. Explanatory posters should be used for example at appropriate conferences and meetings, and attractive stickers on vehicles of all kinds that are likely to catch the public's eye. The most attractively effective ones of which I know so far have been produced by the Indian Society of Naturalists (INSONA) at the instance of our good friend, Dr G.M. Oza (1982; cf. Polunin, 1982, and our present Fig. 1). Television shows can be particularly effective, and our colleague Dr J.R. Vallentyne (e.g. 1984) reckons that he has reached hundreds of millions of viewers very widely in the world by this means-see his account of 'Johnny Biosphere' on pp. 363-4 of this issue, and also our Fig. 2.

3) Employing instructive advertising and audienceattracting showmanship:-One of the prevailing means of changing people's attitudes is through improving their knowledge and understanding by dignified advertising in various media-including those already mentioned, and accurate newspaper notices and announcements. Unfortunately, media advertising is apt to be far too costly for the widely impecunions environmental movement to pay for, whereas governments and major industries cannot afford to let happen the kinds of things that ecologists and realistic demographers feel bound to warn them about. Herein should lie the basis of bilaterally beneficial bill-footing for dignified advertising on behalf of The Biosphere.

4) Books on The Biosphere and illustrated studymanuals:-Obvious desiderata which scarcely need explaining, are our colleague Dr John R. Vallentyne's displays of what he calls 'audience-attracting showmanship', with his sonic globe on his back and broadcasting to many millions (see also above).

5) Specialist research and its vigorous application:Although it is true that the answers to many looming or predictable questions are known (at least to enlightened research workers), and that what is now widely needed is due application of such knowledge, there can scarcely be too much basic research and applicational testing of pertinent results emanating from it. Moreover, who can tell, at any particular juncture, what research results are pertinent and even important for application?

6) Need to control human numbers and behaviour:Perhaps the most fundamental thing that modern Man has so far failed to do is to control its own numbers, despite having the necessary knowledge and means to do so humanely. The most lamentable shortcoming of lack of control applies even more forcibly to Mankind's failure to curb pressures on its environment. So the remedy 


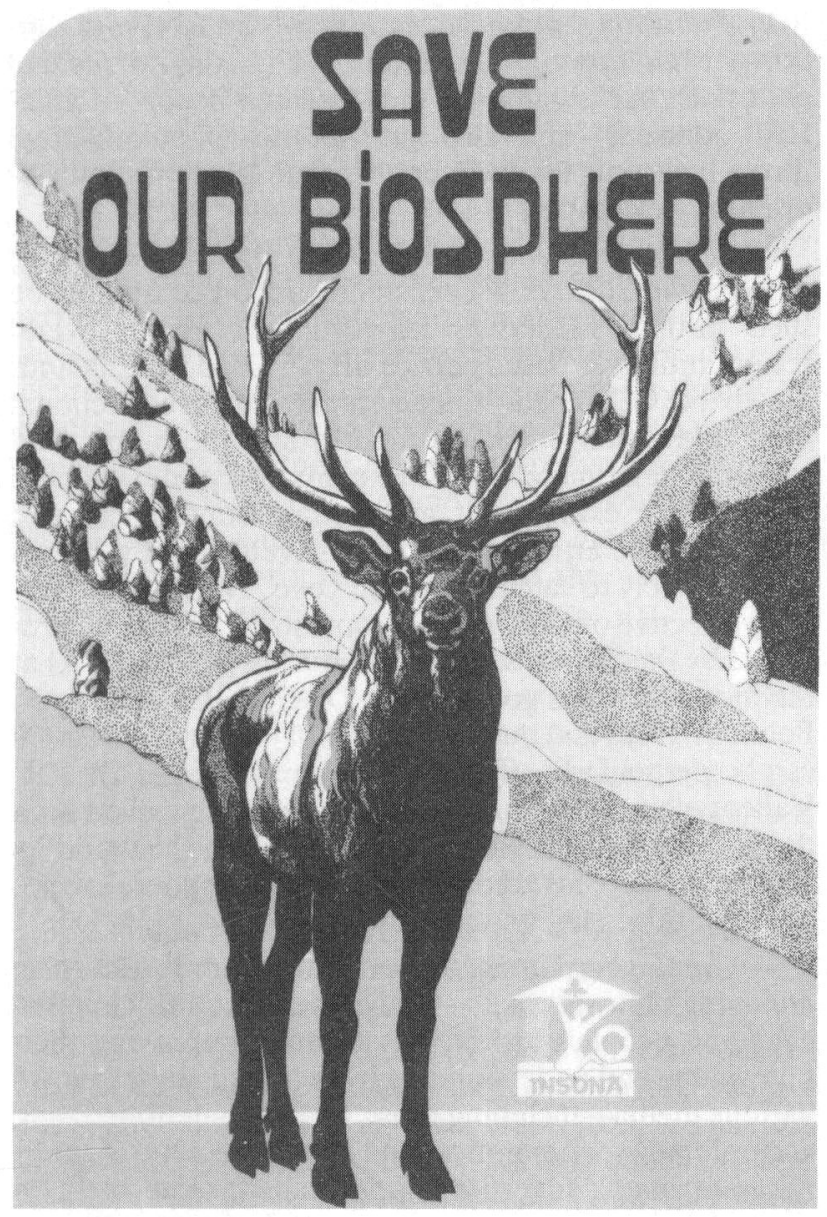

FIG. 1. The Indian Society of Naturalists' (INSONA's) latest 'Save Our Biosphere' sticker, depicting a Kashmir Deer or Hangul (Cervus elaphus hanglu) standing before a largely deforested Himalayan area. The sticker is mainly bright blue, brown, and green, and its dimensions are ca 18 by $12 \mathrm{~cm}$.

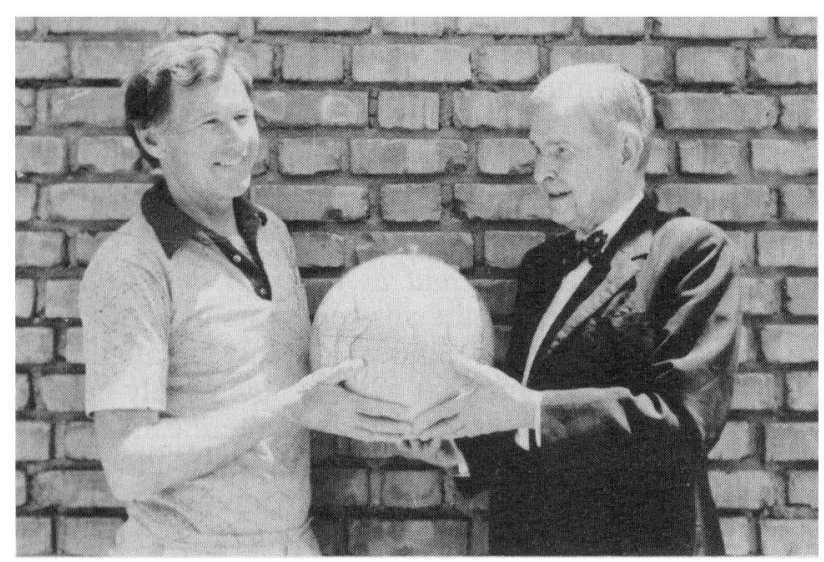

FIG. 2. Two World Campaign for The Biosphere leaders symbolically supporting 'the globe' in Srinagar, India, June 1984. The modern brick wall is also smbolic: when a situation is allowed to deteriorate to the extent that it becomes biospheral, people are virtually backed against a wall. So why the smiles? Because the Campaign is in action, and people in more and more regions and walks of life are talking about The Biosphere and relating their lives to it as the sole life-support. is left to Nature's ways of shortage and deprivation, famine and/or pestilence, and to Mankind's own way of increasing violence and slaughter. Yet, this ever-worsening situation has to be remedied if our World is not to deteriorate further and further into a plethora of dreary monocultures and widespread squalor. Of the need for proper remedy, environmental education and due awareness should at least provide an overview warning, while pointing the way widely to stewardly care and ultimate amelioration-hence the new WCB-ISEE dual establishment to carry on the World Campaign for The Biosphere as explained by Davis (1983).

7) National Parks, Biosphere Reserves, and biological gardens, etc.:-The National Parks and Protected Areas Movement has gathered considerable momentum in recent years, inter alia in relation to the rights of indigenous peoples and some integration with 'development' and even military preparedness. It is now extending actively in to the marine environment, while further valuable educational tools include the Man and the Biosphere (MAB) programme (Batisse, 1980) and the now practically world-wide network of Biosphere Reserves (Batisse, 1982). The inspiration to be derived from communion with Nature in a wilderness can be supreme, as the poets have repeatedly demonstrated, and such communion can be an aesthetic experience leading to productive enlightenment or more. We also believe that the establishment forthwith of what might be called a 'world wilderness alliance'- of similarly-oriented bodies that would, for instance, stand and act together if any of their members was attacked by developmental incursions or unenlightened officialdom-should be urgently considered.

8) Conferences, meetings, and other 'free' deliberation:-The active pursuance of the World Campaign for The Biosphere should be marked by widespread but dignified publicity. It should be fostered and furthered at and by our Third International Conference on Environmental Future, which is being replanned to include extensive elucidation of problems of The Biosphere and its equable maintenance, by the North American Association for Environmental Education, which we understand is including extensive consideration of problems of the environment of Man and Nature in the context of The Biosphere, and by various other actions now under consideration but of which it is hoped details will emerge soon.*

9) Imperative to change human attitudes and priorities:-It is important that people's attitudes towards the future should change still' more widely than to date in consideration of 'generations yet unborn', and seems only right to preserve options for these latter by such means as limiting ourselves to efficient use of the remaining stocks of certain essential minerals and fossil fuels. There is also a dire need to change quite radically our attitudes vis-à-vis 'workers on the land' and 'traditional peoples', for they are the ones who surely know most

\footnotetext{
* See, for example, our 'Keynote Address: To battle for The Biosphere' published on pp. 1-9 of The Biosphere: Problems and Solutions, Edited by T.N. Veziroglu (Elsevier, Amsterdam-Oxford-New York-Tokyo: xv +712 pp., illustr., 1984.
} 
intimately their own small piece of The Biospherewhatever they may call it-moreover understanding its needs and how it can best be maintained and fostered. Indeed it may well prove to be ultimately on them, rather than on politicians or industry or even big Agribusiness that, with the erosion or ignorant destruction of moreand-more of our life-support system, the contemporary residue of humanity may find themselves dependent on for food and much else.

10) Need to establish new ethics and laws:-In their aggregate paper 'Ethics of Biospheral Survival', contributed from the vantage-point of cultures based on four different continents, five eminent authors emphasized the need for fresh thinking and ethics on behalf of The Biosphere (Willard et al., 1980), while two full professors of law from different continents (Widman \& Schram, 1980) dealt with the hopes for 'Common Laws for Earth and Mankind' in a similarly innovative fashion. Those papers were prepared for, and presented in outline at, our Second International Conference on Environmental Future, which was held in Reykjavik, Iceland, in 1977, and engendered long and lively discussions which, with the papers, were published for the most part in the Conference proceedings. But much of that kind of consideration-of ethics and laws and concomitant action towards their utlimate implementation-is urgently needed. ${ }^{*}$ For without duly ethical thinking 'in the corridors of power', and along the wider tracks that lead to them and in edicts that stem from them, there can be little room for hope for a solidly better world, while one of the most obvious needs for the future will surely be suitable laws and their enforcement for Mankind and Nature somehow together.

11) Institutional and organizational involvement towards equitable survival:- It is important that a large number and wide range of leading international organizations and institutions, national and other academies and associations, and university and other departments and research establishments, etc., comprehend the concept and full significance of The Biosphere, and participate in fostering the Campaign for its healthy maintenance in what we hope will be perpetuity.

12) 'Guardians of The Biosphere'-Recognition and awards:-We are firmly convinced that substantial betterment would accrue to the prospects for survival of our tottering world if only people everywhere would learn about The Biosphere and realize their responsibilities, as its intellect-endowed stewards, to preserve and foster it in all possible ways, applying this stewardship to their day-to-day as well as longer-term actions. Should not such learning and cognate behaviour take the place of the fervoured discipline (for example, stemming from religious beliefs but without the spiritual tyranny that is still imposed by some even today) whose erosion in the modern world is so deeply to be deplored? To become thus the profoundly conscious (and why not offically recognized?) Guardians of The Biosphere, should give to all

\footnotetext{
${ }^{*}$ According to two recent visitors to our headquarters in Geneva, Switzerland, there is now a considerable literature on both of these topics.
}

such adherents a 'missionary' feeling of hoped-for accomplishment and lasting 'togetherness'. A pervading attitude of: 'this is our Biosphere to cherish and maintain', should then underlie their concerted resolve to preserve peace on Earth and do all in their power, individually and collectively, to assure for Mankind and Nature a lastingly robust future. True Guardians of the Biosphere should be universally recognized as feeling and duly practising their full responsibilities towards ensuring this. Meanwhile it will be interesting to see what comes from a planned attempt to explain, in the context of The Biosphere, this theme of responsible stewardship to an agricultural audience at Agro-China'84 as outlined on page 364 of this issue.

\section{Initiation of the Adopting World Council}

Our immediate reaction to conceiving the idea of a World Decade of The Biosphere was to pass it on to a global body that we thought would make a good job of promoting it, and who warmly welcomed it at first; but after a year they asked us to take it back and give it a push. This we did as a duty and temporary expedient, and so were considerably relieved and gratified when, at the meetings of the newly-restyled North American Association for Environmental Education, held in Ypsilanti, Michigan, in October 1983, the World Council for The Biosphere was established which recently held, in New Delhi and Srinagar, India, its first general assembly and workshop in close association with its twin the International Society for Environmental Education (see pp. 371-3 of this issue).

Moves towards this emergent twinned WCB-ISEE probably started with the visit which Craig Davis paid to us in Toronto, Canada, in June 1982, when he was President of the then-styled National Association for Environmental Education; now he is of course a moving spirit behind our World Council For The Biosphere, which it is my personal resolve to back and support in every way that I can, while adjuring all fellow Counsellors and associates to do likewise. His responsibilities are great indeed - not less than to the world at large - and he must not be allowed to shoulder them alone, strong and evervigilant though his administration needs to be.

\section{Some Possible Actions of the Dual WCB-ISEE}

Being personally on my final way out so far as any responsibility for, much less leadership of, the World Campaign For The Biosphere is concerned, and without I trust risking any aura of meddling or attempted dictation to others as to how I think they should proceed, I would like, nevertheless, among a welling stream of thoughts as to what needs to be done, to present two further suggestions based inter alia on earlier experience.

The first of these is to stress and further in every possible way the educational aspects of the World Campaign for The Biosphere, for which I am convinced there is grave need and also a call that could be world-wide. For before and after all, The Biosphere is our sole and total life-support and also that of Nature. Such a campaign could presumably best be promoted by strong leadership from an actively vocal ISEE - with, foreseeably, national and other affiliates throughout the world. Meanwhile it 
is gratifying to note-whether or not as a result of our efforts-the increasing number of seminars etc. that are being held by other organizations on The Biosphere or special aspects of it. ${ }^{*}$

The second merest suggestion would be in emulation of my abortive 'World Famine Warning System' of the late 1960s. The idea behind that was to have a small body of leading but independent experts (including some known to hold divergent views) in each of the 50 or so fields of scientific or other endeavour involved in the overall topic, with three joint chairmen who would be respected world leaders, on receipt of a communication from whom any head of state or government would sit up and be inclined to act on grave warnings-in this case of any impending disaster that could be diverted or alleviated by concerted action.

\section{Beneficial Handover}

When A.G. Tansley 'Handed on the torch' of the New Phytologist, which he had founded rather many years previously and had edited I think ever since, and rather similarly with the Journal of Ecology, it was to make room in his busy life for other things. They turned out to be his now classic The British Isles and Their Vegetation, and the establishment and first chairmanship of the British Nature Conservancy, which soon became a model for the world. In far more modest ways, I, too, have other things to get on with, including another International Conference on Environmental Future and a new Environmental Policy Series of books. But allow me, please, as I hand over any reins-except as a Councillor and, I suppose, in connection with the sponsorship of our Foundation - that I may have continued holding, to express the ardent hope that WCB-ISEE will henceforth foster a model of a world made increasingly knowledgeable of itself, and hence happier than could well be the case otherwise. For at the other extreme, ignorance could lead to death--most terrifyingly with the fantastic build-up of nuclear detonation capacity that is currently equivalent to nearly three tonnes of TNT for each of the 4,700 thousand million humans on Earth!

\section{SUMMARY}

Starting with some clarifying definitions of the senses in which the key words in its title are used, this paper outlines the concept and actuality of The Biosphere, which is defined as 'The integrated living and life-supporting system comprising the peripheral envelope of Planet Earth together with its surrounding atmosphere so far down, and up, as any form of life exists naturally.' Two 'round- dozens' of the key facts about The Biosphere are then given-including Mankind's constitution of an integral part of it as well as utter dependence on it and yet increasing threat to it-with emphasis on the vital importance of understanding and fostering it as our own

\footnotetext{
* Recent examples include the Miami International Symposium on The Biosphere (described on page 189 of our Summer issue) and the symposium on 'Global Habitability: The Biosphere', held as part of the 35th Congress of the International Astronautical Federation. The proceedings of the Miami Symposium have now been published-see footnote on p. 296.
}

and Nature's sole life-support. To such understanding and concomitant fostering for survival, education is the key, and to such ends the World Campaign for The Biosphere was developed through various stages and finally declared on World Environment Day 1982 with the No. 1 aim of making the concept and reality of 'Our Biosphere intimately and personally meaningful to people of all ages and cultures throughout the world.'

Most of the second half of the paper is devoted to 12 chosen means of furthering the World Campaign for The Biosphere, including dignified publicity in various media, suitable publications and seminars etc., maintenance of special component areas for research and other purposes, and the dire need to control human numbers and behaviour.

Finally the adoption of the Campaign by a subsequently-established World Council For The Biosphere is welcomed-which Council is to act in concert with, and largely through, its twin (sharing a Secretariat in Columbus, Ohio) organization, the International Society For Environmental Education.

\section{REFERENCES}

ANON. (1982). Declaration: The World Campaign for The Biosphere. Environmental Conservation, 9(2), pp. 91-2.

BATISSE, Michel (1980). The relevance of MAB. Environmental Conservation, 7(3), pp. 73-84, map.

BATISSE, Michel (1982). The Biosphere Reserve: A tool for environmental conservation and management. Environmental Conservation, $9(2)$, pp. 101-11, 8 figs.

Davis, Craig B. (1983). The World Council For The Biosphere/ International Society For Environmental Education. Environmental Conservation, 10(4), pp. 353-4.

OzA, G.M. (1982). Save trees, save our Biosphere! Environmental Conservation, 9(3), pp. 255-6., fig.

Pauling, Linus, Benavides, Felipe, Wahlen, Friedrich T., Kassas, Mohamed, Vohra, B.B. \& KnOX, George A. (1982). Open Letter: To all who should be concerned. Envionmental Conservation, 9(2), pp. 89-90.

Polunin, Nicholas (1972). The Biosphere today. Pp. 33-52 and following discussion etc. to p. 64 in The Environmental Future (Proceedings of the first International Conference on Environmental Future, held in Finland from 27 June to 3 July 1971), Ed. N. POLUNIN. Macmillan, London \& Basingstoke, England, and Barnes \& Noble, New York, NY, USA: xiv + 660 pp., illustr.

Polunin, Nicholas (1982). Our global environment and The World Campaign for The Biosphere, Environmental Conservation, 9(2), pp. 115-21, 2 figs.

VALlentYNe, John R. (1984). 'Johnny Biosphere'. Environmental Conservation, 11(4), p. 363-4, 2 figs.

Widman, Gary L. \& Schram, Gunnar G. (1980). Common laws for Earth and Mankind: A glorious hope? Pp. 555-68 and following discussion to p. 579 in Growth Without Ecodisasters? (Proceedings of the Second International Conference on Environmental Future [2nd ICEF], held in Reykjavik, Iceland, 5-11 June 1977), Ed. N. Polunin. Macmillan Press, London \& Basingstoke, England, and Halsted Press of John Wiley \& Sons, New York, NY, USA: xxvi +675 pp. illustr.

Willard, Beatrice E., Asibey, Emmanuel O.A., Holdgate, Martin W., FukUSHIMA, Yoichi \& GRAY, Elizabeth and David Dodson (1980). Pp. 505-35 and discussion to p. 551 in Growth Without Ecodisasters? (As preceding reference.) 